\title{
PENGARUH KUALITAS PELAYANAN DAN HARGA TERHADAP KEPUASAN KONSUMEN PADA CV. NETRAL KECAMATAN RENGAT KABUPATEN INDRAGIRI HULU
}

\author{
Kurnia Dewi \\ Sekolah Tinggi Ilmu Ekonomi Indragiri Rengat \\ E-mail: kurniadewi@stieindragiri.ac.id
}

\begin{abstract}
This research is on CV. Netral Rengat District, Indragiri Hulu Regency. The purpose of this research is to know the effect of service quality and price simultaneously on customer satisfaction on CV. Neutral Rengat District, Indragiri Hulu Regency; To find out the effect of service quality partially on customer satisfaction on CV. Neutral Rengat District, Indragiri Hulu Regency; To find out the effect of prices partially on customer satisfaction on CV. Neutral Rengat District, Indragiri Hulu Regency. The population in this study are all consumers who use the services of CV. Neutral Rengat Subdistrict, Indragiri Hulu Regency which is infinite in number, where visitors are teenagers to adults, the population used is 24,057 people. While the sample in this study amounted to 100 people with a nonprobability sampling technique. Thisr research used quantitative methods, namely by multiple linear regression, correlation coefficient and determination, and $F$ test and t test. Based on the results of the research and discussion, some conclusions can be drawn as follows: From the quantitative calculations obtained using the multiple linear regression equation $Y=a+b 1 X 1+b 2 X 2$ obtained $Y=3.808+0.238 X 1+0.528$ $X 2$, namely the constant coefficient value (a) amounting to 3.808 this means that if the value of service quality $(X 1)$ and price $(X 2)$ equals zero, then the level or amount of customer satisfaction $(Y)$ is equal to 3.808. The coefficient value of X1 $=0.238$ means that if the service quality $(X 1)$ rises by one unit, while the price variable $(X 2)$ remains, customer satisfaction $(Y)$ will increase by 0.238 and vice versa if the service quality $(X 1)$ decreases by one unit, while the price variable (X2) remains, consumer satisfaction $(Y)$ will decrease by 0,238 . The coefficient value of $X 2=0.528$ explains that if the price $(X 2)$ rises by one unit, while the service quality variable $(X 1)$ remains, the level of customer satisfaction $(Y)$ will increase by 0.528 and if the price $(X 2)$ falls by one unit, while the service quality variable (X1) remains that consumer satisfaction $(Y)$ will decrease by 0.528 . Multiple linear correlation coefficient $(R)$ that is 0.885 means that the relationship that has a very high correlation between service quality and price to customer satisfaction is 0.885 . The coefficient of determination $(R 2)$ is 0.783 , meaning that customer satisfaction can be explained by variations in changes in the independent variable (service quality and price) of $78.3 \%$, while the remaining $21.7 \%$ is explained by other variables outside the research. Based on the results of the $F$ test, the calculated $F$ value is 175,051 with a significant level of 0,000. While Ftable at 100\% (0.05) is 3.09. In both calculations, F count $>$ Ftable is 175,051 > 3,09. This means that Ho is rejected and Ha is accepted, meaning that simultaneously service quality and price have a significant effect on customer satisfaction. Based on the results of the t test obtained the value of tcount XI>t table = 2.101> 1.98447 so that Ho is rejected and Ha is accepted, which means the independent variable (X1) service quality partially has a significant effect on the variable customer satisfaction (Y). Furthermore, the value of tcount X2> t table $=4.268>1.98447$ so that Ho is rejected and Ha is accepted, which means that the independent variable (X2) price partially has a significant effect on the variable customer satisfaction $(Y)$.
\end{abstract}

Keywords: Service Quality, Price, Consumer Satisfaction

\section{A. PENDAHULUAN}

Globalisasi menyebabkan semakin tingginya perdagangan yang tidak mengenal batas-batas negara. Kekuatan global akan terus mempengaruhi kehidupan masyarakat dunia. Teknologi pun semakin meningkat yang dapat mengakibatkan persaingan yang tinggi di antara perdagangan dan pengusaha hingga tidak ada pembatasan yang dapat melindungi perdagangan suatu negara. Para pengusaha bebas memutuskan apa yang harus dijual, sehingga strategi bisnis akan beresiko.
Jika perusahaan dapat menjaring pelanggan sebanyak-banyaknya tentu perusahaan tersebut dapat memperoleh keuntungan yang besar pula. Dinamika dalam dunia usaha yang semakin menantang, membuat para perusahaan harus dapat menjawab tantangan pasar dan memanfaatkan tantangan tersebut sebagai peluang untuk dapat bertahan dimasa yang akan datang.

Keberhasilan suatu perusahaan dipengaruhi oleh bagaimana perusahaan memuaskan pelanggan. Kepuasan 
pelanggan secara individu sangat sulit dicapai karena keanekaragaman keinginan pelanggan iu sendiri, oleh karena itulah pelayanan konsumen hendaknya diarahkan kepada pelayanan yang berkesinambungan. Salah satunya dibidang sektor jasa, dalam kegiatan ekonomi yang berkembang seperti sekarang ini. Peranan industri jasa Angkatan Antar-Jemput ( Travel ) semakin dibutuhkan masyarakat karena siiring dengan meningkatnya keperluan mereka dan juga untuk mendapatkan kenyamanan dalam bepergian.

Sebagai salah satu Angkutan AntarJemput CV. Netral Kecamatan Rengat Kabupaten Indragiri Hulu untuk mempertahankan kepuasan pelanggannya, agar pelanggan tidak berpaling ke perusahaan lain, kualitas layanan yang tinggi dan harga yang terjangkau akan menghasilkan kepuasan pelanggang yang tinggi. Dengan jumlah karyawan yang mencapai lebih dari sepuluh (10) orang, tentunya hali ini menjadi keunggulan, sebab dalam memberikan pelayanan dapat dilakukan dengan maksimal, tanpa harus membuat konsumen kecewa dan menunggu untuk melayani booking tiket jasa yang dipesan konsumen.

Cara mempertahankan kualitas pelayanan yang di hasilkan oleh CV. Netral Kecamatan Rengat Kabupaten Indragiri Hulu dengan memberikan pelayanan yang menyenangkan dan ketangkasan dalam bekerja, serta memberikan sikap ramah, sopan, dan memberikan jaminan akan kenyamanan pelanggan. Untuk melihat pertumbuhan jumlah konsumen yang menggunakan jasa antar- jemput di CV. Netral Kecamatan Rengat Kabupaten Indragiri Hulu pada tahun 2014-2018 dapat dilihat pada tabel di bawah ini:

Tabel 1 Jumlah Konsumen danPertumbuhan pada CV. Netral Kecamatan Rengat

Kabupaten Indragiri Hulu tahun 2014-2018

\begin{tabular}{|c|c|c|c|}
\hline No. & Tahun & Jumlah Konsumen & Persentase $(\%)$ \\
\hline 1. & 2014 & 27.130 orang & - \\
\hline 2. & 2015 & 29.040 orang & $6,6 \%$ \\
\hline 3. & 2016 & 30.240 orang & $4,0 \%$ \\
\hline 4. & 2017 & 25.173 orang & $-20,1 \%$ \\
\hline 5. & 2018 & 24.057 orang & $-4,6 \%$ \\
\hline
\end{tabular}

Sumber : CV. Netral Kecamatan Rengat Kabupaten Indragiri Hulu, tahun 2019.

Eko dan Bisnis (Riau Economics and Business Reviewe) Volume 10, Nomor 3, 27 September 2019
Berdasarkan tabel 1 diatas dapat dilihat jumlah konsumen yang mengunakan jasa antar-jemput di CV. Netral Kecamatan Rengat Kabupaten Indragiri Hulu, selama lima tahun mengalami kenaikan dan penurunan, dan pada tahun 2018 jumlah konsumen 24.057 orang dan mengalami penurunan dengan persentase $-4,6 \%$.

Sedangkan untuk harga tiket yang ada pada CV. Netral Rengat Kabupaten Indragiri Hulu dapat dilihat pada tabel berikut:

Tabel 2 Harga Tiket pada CV. Netral Kecamatan Rengat Kabupaten Indragiri Hulu tahun 2014-2018

\begin{tabular}{|c|c|c|c|c|}
\hline \multirow{2}{*}{ No. } & \multirow{2}{*}{ Tahun } & \multicolumn{3}{|c|}{ Tujuan Dan Harga Tiket (Rp) } \\
\cline { 3 - 5 } & & Rengat-PKU & Rengat-Dumai & Rengat-Jambi \\
\hline 1. & 2014 & Rp. 120.000 & Rp. 230.000 & Rp. 110.000 \\
\hline 2. & 2015 & Rp. 120.000 & Rp. 230.000 & Rp. 110.000 \\
\hline 3. & 2016 & Rp. 130.000 & Rp. 250.000 & Rp. 120.000 \\
\hline 4. & 2017 & Rp. 130.000 & Rp. 250.000 & Rp. 140.000 \\
\hline 5. & 2018 & Rp. 140.000 & Rp. 270.000 & Rp. 150.000 \\
\hline
\end{tabular}

Sumber : CV. Netral Kecamatan Rengat Kabupaten Indragiri Hulu, tahun 2019

Berdasarkan tabel 2 diatas mengenai Harga tiket pada CV. Netral Kecamatan Rengat Kabupaten Indragiri Hulu, mengalami kenaikan pada tahun 2018.

Penelitian oleh Nico Pratama Onasie (2015). "hasil penelitian; Secara simultan kualitas pelayanan dan harga terdapat korelasi positif terhadap kepuasan konsumen. Dan Secara parsial kualitas interaksi, kualitas lingkungan fisik, kualitas hasil dan harga berpengaruh positif dan signifikan terhadap kepuasan konsumen.

\section{Kepuasan Konsumen}

Kepuasan konsumen adalah tingkat perasaan konsumen setelah membandingkan antara apa yang dia terima dan harapannya (Umar, 2013: 65).

Kepuasan konsumen adalah perasaan senang atau kecewa seseorang yang muncul setelah membandingkan kinerja (hasil) produk yang dipikirkan terhadap kinerja yang diharapkan (Kotler, at. al, 2008: 177).

Kepuasan konsumen adalah tingkat perasaan seseorang setelah membandingkan (kinerja atau hasil) yang dirasakan dibandingkan dengan harapannya. 
Konsumen dapat mengalami salah satu dari tiga tingkat kepuasan umum yaitu kalau kinerja di bawah harapan, konsumen akan merasa kecewa tetapi jika kinerja sesuai dengan harapan pelanggan akan merasa puas dan apa bila kinerja bisa melebihi harapan maka pelanggan akan merasakan sangat puas senang atau gembira (Sunyoto, 2013: 35).

\section{Kualitas Pelayanan}

Kualitas pelayanan adalah merupakan tingkat keunggulan (excellence) yang diharapkan dan pengendalian atas keunggulan tersebut untuk memenuhi keinginan pelanggan (Lovelock, 2011: 260).

Pelayanan adalah setiap tindakan atau kegiatan yang dapat ditawarkan oleh suatu pihak kepada pihak lain, yang pada dasarnya tidak berwujud dan tidak mengakibatkan kepemilikan apapun. Produksinya dapat dikaitkan atau tidak dikaitkan pada satu produk fisik. Pelayanan merupakan perilaku produsen dalam rangka memenuhi kebutuhan dan keinginan konsumen demi tercapainya kepuasan pada konsumen itu sendiri (Kotler, 2010: 83).

\section{Harga}

Harga adalah sejumlah uang yang dibayarkan atas jasa, atau jumlah nilai yang konsumen tukar dalam rangka mendapatkan manfaat dari memiliki atau menggunakan barang atau jasa (Kotler dan Amstrong, 2009: 430).

Ada empat ukuran yang mencirikan harga, adalah: keterjangkauan harga, kesesuaian harga dengan kualitas, kesesuaian harga dengan manfaat, dan harga sesuai kemampuan atau daya beli. (Kotler dan Amstrong, 2012: 314):

\section{Kerangka Pemikiran}

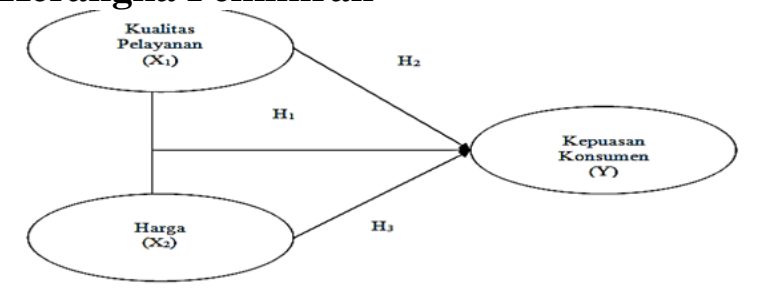

Gambar 1: Kerangka Pemikiran

Eko dan Bisnis (Riau Economics and Business Reviewe) Volume 10, Nomor 3, 27 September 2019

\section{Hipotesis}

1. Diduga kualitas pelayanan dan harga secara simultan berpengaruh signifikan terhadap kepuasan konsumen pada CV. Netral Kecamatan Rengat Kabupaten Indragiri Hulu.

2. Diduga kualitas pelayanan secara Parsial berpengaruh signifikan terhadap kepuasan konsumen pada CV. Netral Kecamatan Rengat Kabupaten Indragiri Hulu.

3. Diduga harga secara Parsial berpengaruh signifikan terhadap kepuasan konsumen pada CV. Netral Kecamatan Rengat Kabupaten Indragiri Hulu.

\section{METODE}

\section{Lokasi Penelitian}

Pada CV. Netral Kecamatan Rengat Kabupaten Indragiri Hulu, dengan alamat di Jalan Sultan Kecamatan Rengat Kabupaten Indragiri Hulu.

\section{Jenis dan Sumber Data}

a. Data Primer adalah data yang diperoleh langsung dari lapangan yang berasal dari responden sebagai objek penelitian.

b. Data Sekunder adalah data yang diperoleh melalui pihak lain diluar responden yang sudah ada pada CV. Netral Kecamatan Rengat Kabupaten Indragiri Hulu..

\section{Populasi dan Sampel Populasi}

Dalam penelitian ini meliputi seluruh konsumen yang menggunakan jasa CV. Netral Kecamtan Rengat Kabupaten Indragiri Hulu. Jumlah populasi yang digunakan adalah 24.057 orang.

\section{Sampel}

Sampel adalah bagian jumlah dan karakteristik yang dimiliki oleh populasi tersebut (Sugiyono, 2008: 91). Pengambilan sampel dalam penelitian ini dilakukan dengan menggunakan metode nonprobability sampling yaitu teknik 
pengambilan sampel yang tidak memberi peluang atau kesempatan sama bagi setiap unsur anggota populasi untuk dipilih menjadi sampel.

Dalam pengambilan sampel pada penelitian ini, penulis menggunakan rumus slovin yaitu sebagai berikut:

$$
\mathrm{n} \quad=\frac{\mathrm{N}}{1+\mathrm{N} \mathrm{e}^{2}}
$$

Dimana:

$\mathrm{n}=$ Jumlah sampel

$\mathrm{N}=$ Populasi

$\mathrm{e}=$ Presisi, akibat kesalahan pengambilan sampel yang dapat ditolelir $(=0,1)$

Dan rumus slovin di atas maka sampel dari penelitian ini adalah sebagai berikut:

$$
\begin{aligned}
& \mathrm{n}=\frac{\mathrm{N}}{1+\mathrm{N} \mathrm{e}^{2}} \\
& \mathrm{n}=\frac{24.057}{1+24.057(0,1)^{2}} \\
& \mathrm{n}=\frac{24.057}{1+240,57} \\
& \mathrm{n}=\frac{24.057}{241,57} \\
& \mathrm{n}=100,58 \\
& \mathrm{n}=100 \text { responden }
\end{aligned}
$$

\section{Teknik Pengumpulan Data}

1) Kuesioner yaitu penulis mengadakan pengumpulan data dengan cara memberikan daftar pertanyaan kepada responden.

2) Wawancara yaitu proses memperoleh keterangan untuk tujuan penelitian dengan cara tanya jawab.

\section{Analisis Data}

\section{Regresi Linear Berganda}

$\mathrm{Y}=\mathrm{a}+\mathrm{b}_{1} \mathrm{X}_{1}+\mathrm{b}_{2} \mathrm{X}_{2}$

Dimana:

$\mathrm{Y} \quad=$ Kepuasan konsumen

a $\quad=$ konstanta

$\mathrm{b}_{1}, \mathrm{~b}_{2}=$ koefisien regresi dan

$\mathrm{X}_{1} \quad=$ Kualitas pelayanan

Eko dan Bisnis (Riau Economics and Business Reviewe) Volume 10, Nomor 3, 27 September 2019
$\mathrm{X}_{2} \quad=$ Harga

\section{Koefisien Korelasi Berganda (R)}

Koefisien korelasi berganda (R) merupakan akar dari koefisien determinasi. Besarnya hubungan antara variabel yang satu dengan variabel yang lain dinyatakan dengan koefisien korelasi yang disimbulkan dengan huruf " $r$ ". Besarnya koefisien korelasi akan berkisar antara -1 (negatif satu) sampai dengan +1 (positif satu). Untuk menganalisis keterkaitan antarvariabel, perlu diukur besarnya nilai koefisien korelasi. Untuk data yang berjenis interval dan rasio digunakan analisis korelasi product moment (r) dengan rumus sebagai berikut:

$R=\sqrt{\frac{r 2 y x 1+r 2 y x 2-2 r y x 1 r y x 2 r x 1 \times 2}{1-r 2 x 1 \times 2}}$

\section{Koefisien Determinasi $\left(\mathbf{R}^{\mathbf{2}}\right)$}

Koefisien determinasi $\left(\mathrm{R}^{2}\right)$ adalah satu ukuran yang digunakan untuk mengukur pengaruh variabel independen terhadap variansi variabel dependen, dengan $0<\mathrm{R}^{2}<1$.

Dengan rumus koefisien determinasi $\left(\mathrm{R}^{2}\right)$ sebagai berikut:

$$
\mathrm{R}^{2}=1-\left(1-\mathrm{R}^{2}\right) \frac{N-1}{N-k}
$$

\section{Uji Hipotesis}

\section{Uji Simultan (Uji F)}

Uji Simultan digunakan untuk mengetahui pengaruh variabel bebas (independen) terhadap variabel terikat (dependen). Dengan rumus:

$$
\mathrm{F}_{\mathrm{o}}=\frac{\mathrm{R}^{2}(\mathrm{n}-\mathrm{k}-1)}{\mathrm{k}\left(1-\mathrm{R}^{2}\right)}
$$
adalah:

Kaidah pengambilan keputusannya

(1) Jika $F_{\text {hitung }}$ signifikan pada taraf $>5 \%$, maka Ho ditolak dan Ha diterima, artinya secara simultan kualitas pelayanan dan harga berpengaruh terhadap kepuasan konsumen.

(2) Jika $F_{\text {hitung }}$ signifikan pada taraf $<5 \%$, maka Ho diterima dan $\mathrm{Ha}$ ditolak, artinya secara simultan kualitas 
pelayanan dan harga tidak berpengaruh terhadap kepuasan konsumen.

(3) Taraf nyata atau derajat keyakinan yang digunakan adalah $\alpha=5 \%, \mathrm{df}=\mathrm{n}-\mathrm{k}-1$

(4) Dengan bentuk hipotesis sebagai berikut: Ho $: b_{1}, b_{2}=0$ Tidak ada pengaruh yang berarti antara kualitas pelayanan dan harga terhadap kepuasan konsumen pada CV. Netral Kecamatan Rengat Kabupaten Indragiri Hulu.

$\mathrm{Ha}: \mathrm{b}_{1}, \mathrm{~b}_{2} \neq 0$ Ada pengaruh yang berarti antara kualitas pelayanan, dan harga terhadap kepuasan konsumen pada CV. Netral Kecamatan Rengat Kabupaten Indragiri Hulu.

\section{Uji Parsial (Uji t)}

Uji $\mathrm{t}$ digunakan untuk menguji koefisien regresi secara parsial atau terpisah dari variabel bebas lainnya. Untuk mengetahui apakah masing-masing variabel bebas berpengaruh terhadap variabel terikat dengan rumus sebagai berikut:

$$
\mathrm{t}_{\text {hitung }} \quad=\frac{b}{s b}
$$
adalah:

Kaidah pengambilan keputusannya

(1) Jika nilai signifikasi $\mathrm{t}>\alpha(0,05)$ atau koefisien $t_{\text {hitung }}$ signifikasi pada taraf $>$ 5\% maka Ho ditolak dan Ha diterima, yang berarti kualitas pelayanan dan harga mempengaruhi kepuasan konsumen.

(2) Jika nilai signifikasi $\mathrm{t}<\alpha(0,05)$ atau koefisien $t_{\text {hitung }}$ signifikasi pada taraf < 5\% maka Ho diterima dan Ha ditolak, yang berarti kualitas pelayanan dan harga tidak mempengaruhi kepuasan konsumen.

(3) Dengan bentuk hipotesis sebagai berikut:

(4) $\mathrm{X}_{1}$ Terhadap $\mathrm{Y}$

Ho $: b_{1}=0 \quad$ Tidak ada pengaruh kualitas pelayanan terhadap kepuasan konsumen pada CV. Netral Kecamatan Rengat Kabupaten Indragiri Hulu.

$\mathrm{Ha}: \mathrm{b}_{1} \neq 0 \quad$ Ada pengaruh kualitas pelayanan terhadap kepuasan konsumen pada CV. Netral Kecamatan Rengat Kabupaten Indragiri Hulu.

(5) $\mathrm{X}_{2}$ Terhadap $\mathrm{Y}$

Eko dan Bisnis (Riau Economics and Business Reviewe) Volume 10, Nomor 3, 27 September 2019
Ho $: b_{2}=0 \quad$ Tidak ada pengaruh harga terhadap kepuasan konsumen pada CV. Netral Kecamatan Rengat Kabupaten Indragiri Hulu.

$\mathrm{Ha}: \mathrm{b}_{2} \neq 0 \quad$ Ada pengaruh harga terhadap kepuasan konsumen pada CV. Netral Kecamatan Rengat Kabupaten Indragiri Hulu

HASIL

Analisis Regresi Linear Berganda Tabel 3: Hasil Analisis Regresi Linear Berganda Coefficients $^{a}$

\begin{tabular}{|c|c|c|c|c|c|c|}
\hline \multirow{2}{*}{\multicolumn{2}{|c|}{ Model }} & \multicolumn{2}{|c|}{$\begin{array}{l}\text { Unstandardized } \\
\text { Coefficients }\end{array}$} & \multirow{2}{*}{$\begin{array}{c}\begin{array}{c}\text { Standardized } \\
\text { Coefficients }\end{array} \\
\text { Beta }\end{array}$} & \multirow[b]{2}{*}{$t$} & \multirow[b]{2}{*}{ Sig. } \\
\hline & & B & Std. Error & & & \\
\hline \multirow[t]{3}{*}{1} & (Constant) & 3.808 & .514 & & 7.408 & .000 \\
\hline & $\mathrm{X} 1$ & .238 & .113 & .296 & 2.101 & .038 \\
\hline & X2 & .528 & .124 & .601 & 4.268 & .000 \\
\hline
\end{tabular}

Sumber: Data Olahan Output SPSS Versi 20.00

Berdasarkan tabel di atas dapat diperoleh persamaan regresi sebagai berikut: $\mathbf{Y}=\mathbf{3 , 8 0 8}+\mathbf{0 , 2 3 8} \mathrm{X}_{\mathbf{1}}+\mathbf{0 , 5 2 8} \mathrm{X}_{\mathbf{2}}$

Dengan mengacu pada persamaan regresi yang diperoleh, maka model regresi tersebut dapat diinterpretasikan sebagai berikut:

Nilai koefisien konstanta (a) sebesar 3,808 hal ini berarti bahwa apabila nilai kualitas pelayanan $\left(\mathrm{X}_{1}\right)$ dan harga $\left(\mathrm{X}_{2}\right)$ sama dengan nol, maka tingkat atau besarnya kepuasan konsumen (Y) sebesar 3,808 .

Nilai koefisien $X_{1}=0,238$ berarti bahwa apabila kualitas pelayanan $\left(\mathrm{X}_{1}\right)$ naik sebesar satu satuan, sementara variabel harga $\left(\mathrm{X}_{2}\right)$ tetap maka kepuasan konsumen (Y) akan mengalami peningkatan sebesar 0,238 dan sebaliknya apabila kualitas pelayanan $\left(\mathrm{X}_{1}\right)$ terjadi penurunan sebesar satu satuan, sementara variabel harga $\left(\mathrm{X}_{2}\right)$ tetap maka kepuasan konsumen (Y) akan mengalami penurunan sebesar 0,238.

Nilai koefisien $X_{2}=0,528$ hal ini menerangkan apabila harga $\left(X_{2}\right)$ naik sebesar satu satuan, sementara variabel kualitas pelayanan $\left(\mathrm{X}_{1}\right)$ tetap maka tingkat kepuasan konsumen (Y) akan mengalami peningkatan sebesar 0,528 dan apabila 
harga $\left(\mathrm{X}_{2}\right)$ turun sebesar satu satuan, sementara variabel kualitas pelayanan $\left(\mathrm{X}_{1}\right)$ tetap maka kepuasan konsumen (Y) akan mengalami penuruan sebesar 0,528.

\section{Analisis Koefisien Korelasi Linear Berganda (R)}

Korelasi berganda digunakan untuk mengetahui tingkat hubungan secara simultan antara variabel $\mathrm{X}_{1}$ dan $\mathrm{X}_{2}$ terhadap variabel $Y$. Dalam hal ini pengaruh yang diteliti adalah pengaruh kualitas pelayanan dan harga terhadap kepuasan konsumen. Hal ini dapat dilihat hasil perhitungan dari data penelitian yang diperoleh dari hasil angket dengan menggunakan SPSS sebagai berikut:

Tabel 4: Koefisien Korelasi Linear Berganda (R)

Model Summary

\begin{tabular}{|l|r|r|r|c|}
\hline Model & $\mathrm{R}$ & R Square & $\begin{array}{c}\text { Adjusted R } \\
\text { Square }\end{array}$ & $\begin{array}{c}\text { Std. Error of the } \\
\text { Estimate }\end{array}$ \\
\hline 1 & $.885^{\mathrm{a}}$ & .783 & .779 & 1.226 \\
\hline
\end{tabular}

Sumber: Data Olahan Output SPSS Versi 20.00

Dari hasil perhitungan diatas diketahui bahwa nilai $\mathrm{R}$ adalah koefisien korelasi yang mengukur arah dan keeratan hubungan antara variabel $X_{1}$ (kualitas pelayanan) dan $\mathrm{X}_{2}$ (harga) dengan variabel $\mathrm{Y}$ (kepuasan konsumen).

Mengenai sifat suatu hubungan atau pengaruh dari kedua variabel tersebut di atas, dapat dilihat pada penafsiran akan besarnya koefisien korelasi yang umum digunakan adalah (Arikunto, 2006: 34):

1) 0,00-0,20 Korelasi rendah sekali

2) 0,21-0,40 Korelasi rendah

3) 0,41-0,70 Korelasi sedang

4) 0,71-0,90 Korelasi tinggi

5) $0,91-1,00$ Korelasi tinggi sekali

Dari kriteria tersebut, maka nilai koefisien korelasi sebesar 0,885 termasuk dalam kriteria $(0,71-0,90)$ yang berarti tergolong dalam kategori korelasi tinggi.

Dari hasil perhitungan di atas menunjukkan terdapat hubungan yang korelasi tinggi sekali antara kualitas pelayanan dan harga terhadap kepuasan konsumen sebesar 0,885 .

\section{Analisis Koefisien Determinasi $\left(\mathbf{R}^{\mathbf{2}}\right)$}

Koefisien determinasi menunjukan berapa persen dari variasi (naik turunnya) variabel dependen dapat diterangkan atau dijelaskan oleh variasi variabel independen. Hal ini dapat dilihat dari model summary yang dihasilkan dengan menggunakan SPSS sebagai berikut:

Tabel 5: Analisis Koefisien Determinasi Model Summary

\begin{tabular}{|l|r|r|r|c|}
\hline Model & $\mathrm{R}$ & $\mathrm{R}$ Square & $\begin{array}{c}\text { Adjusted } \mathrm{R} \\
\text { Square }\end{array}$ & $\begin{array}{c}\text { Std. Error of the } \\
\text { Estimate }\end{array}$ \\
\hline 1 & $.885^{2}$ & .783 & .779 & 1.226 \\
\hline
\end{tabular}

a. Predictors: (Constant), X2, X1

Sumber: Data Olahan Output SPSS Versi 20.00

Dari tabel di atas nilai koefisien determinasi $\left(\mathrm{R}^{2}\right)$ sebesar 0,783. Maka dapat diperoleh keterangan bahwa kepuasan konsumen dapat dijelaskan oleh variasi perubahan variabel independen (kualitas pelayanan dan harga) sebesar 78,3\%, sedangkan sisanya $21,7 \%$ dijelaskan oleh variabel lain di luar penelitian.

\section{Pengujian Hipotesis Uji Simultan (Uji F)}

Uji $F$ dimaksudkan untuk menguji apakah data sampel mewakili data populasi, sehingga data dijadikan dasar untuk membulat variabel. Adapun perhitungan uji hipotesis menggunakan program SPSS dengan hasil perhitungan sebagai berikut:

Tabel 6: Hasil Uji F ANOVA $^{\circ}$

\begin{tabular}{|c|c|c|c|c|c|c|}
\hline \multicolumn{2}{|c|}{ Model } & Sum of Squares & $\mathrm{df}$ & $\begin{array}{l}\text { Mean } \\
\text { Square }\end{array}$ & $\mathrm{F}$ & Sig. \\
\hline \multirow[t]{3}{*}{1} & Regression & 526.294 & 2 & 263.147 & 175.051 & $.000^{\mathrm{a}}$ \\
\hline & Residual & 145.816 & 97 & 1.503 & & \\
\hline & Total & 672.110 & 99 & & & \\
\hline \multicolumn{7}{|c|}{ a. Predictors: (Constant), X2, X1 } \\
\hline b. Dependent Variable: Y & $\begin{array}{l}\text { ndent Variable } \\
\text { er: Data }\end{array}$ & Ylahan Out & C) & Vers & 20.00 & \\
\hline
\end{tabular}

\section{Hipotesis}

Ho : $b_{1}, b_{2}=0$ Tidak ada pengaruh yang berarti antara kualitas pelayanan dan harga terhadap kepuasan konsumen pada CV. Netral Kecamatan Rengat Kabupaten Indragiri Hulu.

Ho : $b_{1}, b_{2} \neq 0$ Ada pengaruh yang berarti antara kualitas pelayanan dan harga terhadap kepuasan konsumen pada CV. 
Netral Kecamatan Rengat Kabupaten Indragiri Hulu.

\section{Dasar Pengambilan Keputusan:}

1) Jika $F_{\text {hitung }}$ signifikan pada taraf $>0,05$, maka Ho ditolak dan $\mathrm{Ha}$ diterima, artinya secara simultan kualitas pelayanan dan harga berpengaruh terhadap kepuasan konsumen.

2) Jika $F_{\text {hitung }}$ signifikan pada taraf $<0,05$, maka Ho diterima dan $\mathrm{Ha}$ ditolak, artinya secara simultan kualitas pelayanan dan harga tidak berpengaruh terhadap kepuasan konsumen.

Level of signifikan $(\alpha) ; \alpha=0,05$

$$
\begin{aligned}
\mathrm{F}_{\text {tabel }} & =\mathrm{k}:(\mathrm{n}-\mathrm{k}-1) \\
& =2:(100-2-1) \\
& =2: 97 \\
& =3,09
\end{aligned}
$$

\section{Intepretasi:}

Pada tabel di atas nilai $\mathrm{F}_{\text {hitung }}$ adalah 175,051 dengan tingkat signifikan 0,000 . Sedangkan $F_{\text {tabel }}$ pada taraf kepercayaan $100 \%(0,05)$ adalah 3,09. Pada kedua perhitungan $\mathrm{F}_{\text {hitung }}>\mathrm{F}_{\text {tabel }}$ yaitu 175,051 > 3,09. Hal ini berarti Ho ditolak dan $\mathrm{Ha}$ diterima, artinya secara simultan kualitas pelayanan dan harga berpengaruh terhadap kepuasan konsumen.

\section{Uji Parsial (Uji t)}

Uji t dimaksudkan untuk menguji apakah variabel independen secara parsial berpengaruh signifikan terhadap variabel dependen. Adapun perhitungan uji hipotesis menggunakan program SPSS dengan hasil

\begin{tabular}{|c|c|c|c|c|c|c|}
\hline \multirow{2}{*}{\multicolumn{2}{|c|}{ Model }} & \multicolumn{2}{|c|}{$\begin{array}{c}\text { Unstandardized } \\
\text { Coefficients }\end{array}$} & \multirow{2}{*}{\begin{tabular}{|c|}
$\begin{array}{c}\text { Standardized } \\
\text { Coefficients }\end{array}$ \\
Beta \\
\end{tabular}} & \multirow[b]{2}{*}{ t } & \multirow[b]{2}{*}{ Sig. } \\
\hline & & B & Std. Error & & & \\
\hline \multirow[t]{3}{*}{1} & (Constant) & 3.808 & .514 & & 7.408 & .000 \\
\hline & $X 1$ & .238 & .113 & .296 & 2.101 & .038 \\
\hline & $X 2$ & .528 & .124 & .601 & 4.268 & .000 \\
\hline
\end{tabular}
perhitungan sebagai berikut:

\section{Tabel 7: Hasil Uji t}

Coefficients $^{\mathrm{a}}$

Hipotesis:

1. $\mathrm{X}_{1}$ Terhadap Y Ho $: \mathrm{b}_{1}=0$ Tidak ada pengaruh kualitas pelayanan terhadap kepuasan konsumen pada CV.
Netral Kecamatan Rengat Kabupaten Indragiri Hulu.

Ho $: b_{1} \neq 0 \quad$ Ada pengaruh kualitas pelayanan terhadap kepuasan konsumen pada CV. Netral Kecamatan Rengat Kabupaten Indragiri Hulu.

1) $X_{2}$ Terhadap $Y$. Ho $: b_{2}=0 \quad$ Tidak ada pengaruh harga terhadap kepuasan konsumen pada CV. Netral Kecamatan Rengat Kabupaten Indragiri Hulu.

Ho $: b_{2} \neq 0 \quad$ Ada pengaruh harga terhadap kepuasan konsumen pada CV. Netral Kecamatan Rengat Kabupaten Indragiri Hulu.

\section{Dasar Pengambilan Keputusan}

1) Jika nilai signifikansi $t<\alpha(0,05)$ atau koefisien $t_{\text {hitung }}$ signifikansi pada taraf $<5 \%$ maka Ho diterima dan $\mathrm{Ha}$ ditolak, yang berarti kualitas pelayanan dan harga tidak berpengaruh kepuasan konsumen.

2) Jika nilai signifikansi $\mathrm{t}>\alpha(0,05)$ atau koefisien $t_{\text {hitung }}$ signifikansi pada taraf > 5\% maka Ho ditolak dan $\mathrm{Ha}$ diterima, yang berarti kualitas pelayanan dan harga mempengaruhi kepuasan konsumen.

Level of signifikan $(\alpha): \alpha=0,05$

$$
\begin{aligned}
\mathrm{t}_{\text {tabel }} & =\alpha / 2:(\mathrm{n}-2) \\
& =0,05 / 2:(100-2) \\
& =0,025: 98 \\
& =1,98447
\end{aligned}
$$

\section{Intepretasi:}

1) Pada tabel di atas nilai $t_{\text {hitung }} X_{1}>t_{\text {tabel }}$ $=2,101>1,98447$ sehingga Ho ditolak dan Ha diterima, yang berarti variabel independen $\left(\mathrm{X}_{1}\right)$ kualitas pelayanan secara parsial berpengaruh terhadap variabel kepuasan konsumen (Y).

2) Selanjutnya nilai $t_{\text {hitung }} X_{2}>t_{\text {tabel }}=$ $4,268>1,98447$ sehingga Ho ditolak dan Ha diterima, yang berarti variabel independen $\left(\mathrm{X}_{2}\right)$ harga secara parsial berpengaruh terhadap variabel kepuasan konsumen (Y). 


\section{SIMPULAN}

a. Dari perhitungan kuantitatif yang diperoleh dengan menggunakan rumus persamaan regresi linear berganda $\mathrm{Y}=\mathrm{a}$ $+\mathrm{b}_{1} \mathrm{X}_{1}+\mathrm{b}_{2} \mathrm{X}_{2}$ diperoleh $\mathrm{Y}=3,808+$ $0,238 \mathrm{X}_{1}+0,528 \mathrm{X}_{2}$, yakni nilai koefisien konstanta (a) sebesar 3,808 hal ini berarti bahwa apabila nilai kualitas pelayanan $\left(\mathrm{X}_{1}\right)$ dan harga $\left(\mathrm{X}_{2}\right)$ sama dengan nol, maka tingkat atau besarnya kepuasan konsumen (Y) sebesar 3,808. Nilai koefisien $X_{1}=0,238$ berarti bahwa apabila kualitas pelayanan $\left(\mathrm{X}_{1}\right)$ naik sebesar satu satuan, sementara variabel harga $\left(\mathrm{X}_{2}\right)$ tetap maka kepuasan konsumen (Y) akan mengalami peningkatan sebesar 0,238 dan sebaliknya apabila kualitas pelayanan $\left(\mathrm{X}_{1}\right)$ terjadi penurunan sebesar satu satuan, sementara variabel harga $\left(\mathrm{X}_{2}\right)$ tetap maka kepuasan konsumen (Y) akan mengalami penurunan sebesar 0,238. Nilai koefisien $X_{2}=0,528$ hal ini menerangkan apabila harga $\left(\mathrm{X}_{2}\right)$ naik sebesar satu satuan, sementara variabel kualitas pelayanan $\left(\mathrm{X}_{1}\right)$ tetap maka tingkat kepuasan konsumen (Y) akan mengalami peningkatan sebesar 0,528 dan apabila harga $\left(\mathrm{X}_{2}\right)$ turun sebesar satu satuan, sementara variabel kualitas pelayanan $\left(\mathrm{X}_{1}\right)$ tetap maka kepuasan konsumen (Y) akan mengalami penurunan sebesar 0,528.

b. Koefisien korelasi linear berganda (R) yaitu 0,885 artinya hubungan yang korelasi tinggi sekali antara kualitas pelayanan dan harga terhadap kepuasan konsumen sebesar 0,885.

c. Koefisien determinasi $\left(\mathrm{R}^{2}\right)$ sebesar 0,783 , artinya kepuasan konsumen dapat dijelaskan oleh variasi perubahan variabel independen (kualitas pelayanan dan harga) sebesar 78,3\%, sedangkan sisanya $21,7 \%$ dijelaskan oleh variabel lain di luar penelitian.

d. Berdasarkan hasil uji $\mathrm{F}$ diperoleh nilai $F_{\text {hitung }}$ adalah 175,051 dengan tingkat signifikan 0,000. Sedangkan $F_{\text {tabel }}$ pada taraf kepercayaan $100 \%(0,05)$ adalah 3,09. Pada kedua perhitungan $\mathrm{F}_{\text {hitung }}>$
$F_{\text {tabel }}$ yaitu 175,051 > 3,09. Hal ini berarti Ho ditolak dan Ha diterima, artinya secara simultan kualitas pelayanan dan harga berpengaruh signifikan terhadap kepuasan konsumen.

e. Berdasarkan hasil uji $t$ diperoleh nilai nilai $t_{\text {hitung }} X_{1}>t_{\text {tabel }}=2,101>1,98447$ sehingga Ho ditolak dan Ha diterima, yang berarti variabel independen $\left(\mathrm{X}_{1}\right)$ kualitas pelayanan secara parsial berpengaruh signifikan terhadap variabel kepuasan konsumen (Y). Selanjutnya nilai $t_{\text {hitung }} X_{2}>t_{\text {tabel }}=$ 4,268 > 1,98447 sehingga Ho ditolak dan Ha diterima, yang berarti variabel independen $\left(\mathrm{X}_{2}\right)$ harga secara parsial berpengaruh signifikan terhadap variabel kepuasan konsumen (Y)

\section{DAFTAR RUJUKAN}

Kotler, and G. Armstrong, 2009, Principle of Marketing, Erlangga, Jakarta.

G. Armstrong, and Keller, K. L, 2008, Manajemen Pemasaran, Erlangga, Jakarta.

Dedy Hariyanto dan Nindria Untarini,2014."Pengaruh Kualitas

Pelayanan Terhadap Kepuasan

Pelanggan Hotel JW Marriot Surabaya".

Kotler, Philip, 2010, Manajemen Pemasaran, Erlangga, Jakarta.

Lovelock, C, Wirtz, J, and Mussr, J, 2011, Pemasaran Jasa Perspektif Indonesia, Erlangga, Jakarta.

Moch. Ghozali ,2014."Pengaruh Kualitas pelayanan dan harga terhadap kepuasan.

Nico Pratama Onasie,2015. "Pengaruh Kualitas Pelayanan dan Harga Terhadap Kepuasan Pelanggan Hotel Bintang Lima Pekanbaru.

Sugiyono, 2008. Metode Penelitian Kunatitatif Kualitatif dan R\&D. Bandung Alfabeta.

Sunyoto, Danang, 2013, Manajemen Sumber Daya Manusia, PT Buku Seru, Jakarta. 
Umar, Husein, 2013, Riset Pemasaran dan

Perilaku Konsumen, PT. Gramedia Pustaka Utama, Jakarta.

Wayan Widya Suryadharma dan Ketut

Nurcahya, 2015. "Pengaruh Kualitas

Pelayanan Terhadap Kepuasan

Pelanggan Hotel Bintang Pesona Di

Denpasar Timur"

Zahrina Fadilah, 2015. "Pengaruh harga terhadap kepuasan pelanggan pada toko online lazada. 